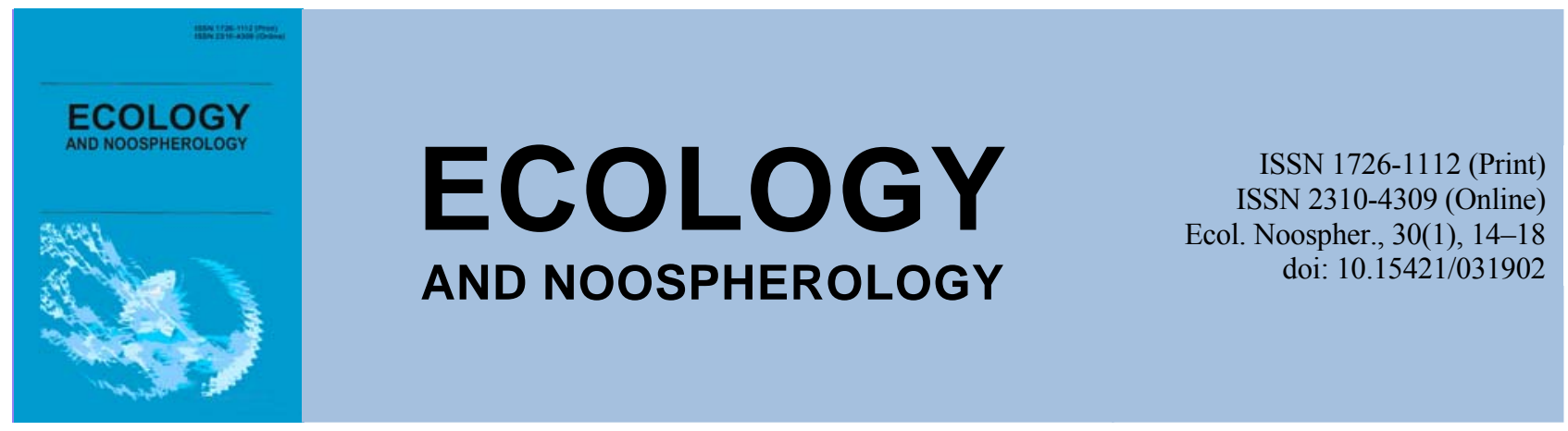

\title{
Ecological features of urease activity distribution in technogenically altered soils of the Nikopol manganese ore basin
}

\author{
V. I. Chorna, I. V. Wagner
}

Dniprovsk State Agrarian and Economic University, Dnipro, Ukraine

Article info

Received 23.03.2019

Received in revised form 28.03.2019

Accepted 05.04.2019

Dniprovsk State Agrarian and

Economic University,

str. Serhiy Yefremov, 25, Dnipro,

49000, Ukraine.

Tel.: +38-097-268-38-71

E-mail:v.ch.49a@gmail.com
Chorna, V. I., Wagner, I. V. (2019). Ecological features of urease activity distribution in technogenically altered soils of the Nikopol manganese ore basin. Ecology and Noospherology, 30(1), 14-18. doi:10.15421/031902

The challenge of degradation of natural ecosystems because of human activity is considered by the world community to the most serious problems facing mankind. As a result of mineral extraction, man-made landscapes and environmentally ruined areas replace natural habitats and agroecosystems; a whole spectrum of man-made processes are typical for such landscapes, which leads to a decrease in species richness and biological diversity within such areas. Degraded territories formed in the process of coal mining are often partially restored through remediation measures. During the implementation of the technical stage of remediation, substrates with different potential fertility having different environmental properties and quality are used. Specific features of distribution total, available nitrogen concentrations and levels of urease enzymatic activity at the layers of artificial soil, sod-lithogenic soils onto gray-green and red-brown clays and on loess-like loams in the Nikopol manganese ore basin are established. It is presented general assessment of technosol status by concentration of general easily hydrolysed nitrogen enzyme activity of urease and this enzyme enriches the soil with mineral nitrogen in the process of mineralization of organic substances. The level of activity of urease, investigated soils, determines the intensity of the direction of biochemical processes that affect soil fertility.High correlation between concentrations of soluble nitrogen and urease activity values by layers of artificial soil $(\mathrm{r}=0.81)$, sod-lithogenic soils onto gray-green $(r=0.98)$, red-brown clays $(r=0.72)$ and onto loess-like loam $(r=0.85)$ were found. Tendency of decreasing hydrolytic enzyme activity, urease, with depth in all types of artificial soil studied was established. It has been established that biochemical diagnostics of technozem processes beyond the level of activity of the hydrolytic enzyme urease makes it possible to estimate the direction of changes at the layers of artificial soil, sod-lithogenic soils onto graygreen and red-brown clays and on loess-like loams. The recultivated soil has some what lower fertility and greater salimity at the lower horizons, but is capable of performing ecological functions and can not only be used for economic purposes, but also perform ecological functions.

Keywords: soil reclamation; technosol; soil enzymes;urease; technogenesis

\section{Екологічні особливості розподілу уреазної активності у техногенно-порушених грунтах Нікопольського марганцеворудного басейну}

\author{
В. І. Чорна, I. В. Вагнер
}

Дніпровський державний аграрно-економічний університет, Дніпро, Україна

Визначено особливості розподілу концентрації загального рухомого азоту і рівней ферментативної активності уреази по шарах педоземів, дерново-літогенних грунтів на сіро-зелених і червоно-бурих глинах та на лесоподібних суглинках Нікопольського марганцеворудного басейну. Надано загальну оцінку стану техноземів за концентрацією легкогідролізованого азоту та активністю гідролітичного ферменту уреази, яка збагачує грунт мінеральним азотом у процесі 
мінералізації органічних речовин. Рівень активності уреази досліджуваних техногенно-порушених грунтів визначає інтенсивність, спрямованість біохімічних процесів, від яких залежить родючість грунту. Установлено високу кореляційну залежність між концентрацією розчинного азоту і рівнем активності грунтової уреази по шарах педоземів $(\mathrm{r}=0,81)$, дерново-літогенних грунтів на сіро-зелених $(\mathrm{r}=0,98)$ і червоно-бурих глинах $(\mathrm{r}=0,72)$ та лесоподібних суглинках $(\mathrm{r}=0,85)$. Установлено, що біохімічна діагностика техноземів за рівнем уреазної активності гідролітичного ферменту уреази дозволяє надати оцінку спрямованості змін родючості грунтів по шарах педоземів та дерново-літогенних грунтів на сіро-зелених, червоно-бурих глинах та лесоподібному суглинку. Використання рівня уреазної активності може бути надійним i перспективним напрямом біомоніторингу едафотопів техногенно-порушених ландшафтів.

Ключові слова: рекультивація; техноземи; грунтові ферменти; уреаза

\section{Вступ}

Одним із важливих показників, які характеризують продуктивність грунтів, є ферментативна активність. Дослідження в цій галузі проводилися багатьма ученими (Tian et al., 2008; Kazeev et al., 2003; Ahmedova et al., 2014), які встановили високу ефективність використання цього показника для діагностики динаміки родючості грунтів за різних антропогенних і природних впливів на екосистеми. Перевагою застосування цього методу $\epsilon$ можливість швидкого визначення змін, які відбуваються в екосистемах на самих ранніх стадіях розвитку деградаційних процесів, прогноз їх спрямованості i ступеня виявлення. Досліджуваний нами фермент належить до класу гідролаз і відіграє істотну роль у гідролітичному розщепленні органічних речовин, збагачуючи грунт доступними для рослин поживними елементами. Уреаза каталізує гідроліз сечовини до вуглекислого газу та аміаку. Аміак, що утворився, слугує джерелом азотного живлення рослин (Dadenko, Kazeev, 2006). У результаті ферментативних процесів поживні речовини 3 важкозасвоюваних сполук переходять у легкодоступні форми для рослин i мікроорганізмів.

Активність ферментів відображає не тільки біологічні властивості грунту, але й їх зміни під впливом агроекологічних факторів. Основні шляхи надходження ферментів у грунт - це прижиттєво виділені позаклітинні ферменти мікроорганізмів i коренів рослин, внутрішньоклітинні ферменти, які потрапили в грунт після відмирання грунтових організмів і рослин.

Ферменти, які потрапили в грунт, значний час зберігають активність завдяки фіксації їх органічною речовиною. Ферментативна активність грунтів визначає інтенсивність і спрямованість біохімічних процесів, від яких залежить родючість грунту, і є одним 3 важливих показників його біологічної активності. Активність ферментів у грунті залежить від їх фізико-хімічних властивостей, засоленості, карбонатності, окультуреності, внесення добрив, вапнування тощо. Дослідженнями встановлено, що у свіжовідсипних породах ферменти відсутні. Згодом (8-10 років) у шарі $0-20$ см визначається наявність ферментів до рівня ферментативного пулу. Після 30-річного перебування порід у паровому стані поверхневий шар літоземів має бідний ступінь збагачення гідролітичними ферментами. У «нуль-момент грунтогенезу» вміст органічної речовини та пов'язаного 3 нею мінерального азоту в літоземах вкрай низький («сліди»). Якщо розглядати літоземи як антропогенну грунтогенну систему, то іiі розвиток здійснюється за рахунок абіотичних i біотичних факторів. Природна реальність формування піонерних, а 3 часом складних фітоценозів на надрудних породах Нікопольського марганцеворудного басейну детально обгрунтована в роботах М. Т. Масюка. Контрольні варіанти едафотопів за ступенем зниження активності гідролітичних ферментів розташовуються в такий ряд: насипний родючий шар чорнозему, сіро-зелена, червоно-бура глина, лесовидний суглинок (Chorna et al., 2018). Культурофітоценози з бобових рослин сприяли значному посиленню процесу накопичення в едафотопах ферментів. На основі багаторічних досліджень складено градацію ступенів біогенності едафотопів за активністю гідролітичних ферментів.

Для шару 0-20 см вона має такий вигляд: абіогенні - це едафотопи, у яких активність ферментів зменшилась більш ніж на $75 \%$ у порівнянні 3 активністю цих ферментів на контрольному варіанті 3 південного чорнозему; слабкобіогенні - активність ферментів зменшилась на 75$50 \%$; середньобіогенні - на 50-25\% і біогенні едафотопи активність гідролітичних ферментів зменшилась на $25 \%$.

Метою даного дослідження $\epsilon$ визначення особливостей розподілу рівнів уреазної активності, загального та доступного азоту у профілях техноземів Нікопольського марганцеворудного басейну по шарах педозему, дерноволітогенних грунтів, на сіро-зелених і червоно-бурих глинах та лесоподібному суглинку.

\section{Матеріали та методи досліджень}

Дослідження активності уреази, загального і доступного азоту проводили в науково-дослідній лабораторії гідроекології Дніпровського державного аграрно-економічного університету (ДДАЕУ). Зразки відбирали на дослідних ділянках науково-дослідного стаціонару з рекультивації земель ДДАЕУ (м. Покров, Дніпропетровська обл.) (Demidov, 2013) із закладенням грунтових розрізів досліджуваних типів техноземів: педозем, дерново-літогенні грунти на сіро-зелених i червоно-бурих глинах на лесоподібному суглинку. Проби відбирали по шарах 0-10, 10-20...90-100 см у триразовій повторюваності. Активність уреази оцінювали за методом Ф. Х. Хазієва (Khaziev, 2005).

Для визначення доступних форм азоту і загального вмісту азоту використовували метод I. В. Тюріна (Tyurin, 1965). Статистична обробка одержаних результатів проведена за допомогою програми Statistica 7.0.

\section{Результати та їх обговорення}

Літоземи як екологічне середовище для самозаростання i вирощування культурних рослин характеризуються специфічним поживним режимом, який відрізняється від блоку загальної грунтової родючості та 3 плином сучасного грунтогенезу еволюційно змінюються. Вміст загального азоту у шарі 0-20 см становить $0,083 \%$ у педоземі, 0,089 \% - лесоподібному суглинку та $0,02 \%$ i $0,016 \%$ - у червоно-бурій та сіро-зеленій глині відповідно. Визначається тенденція зі зниження даного показника для всіх досліджуваних техноземів з глибиною (рис. 1).

За вмістом легкогідролізованого азоту педоземи можна охарактеризувати як грунти з дуже низьким забезпеченням рухомих сполук азоту (рис. 2).

Тільки в орному шарі техноземів на лесоподібному суглинку, червоно-бурій та сіро-зеленій глині забезпеченість обмінним азотом $є$ низькою.

Концентрація легкогідролізованого азоту в орному шарі 0-10 см у техноземах на лесоподібному суглинку та на сіро-зеленій глині становить 0,72 та 0,65 мг/100 г відповідно, що $є$ максимальними значеннями для всіх профілей. Педоземи в шарі 0-40 см за цим показником мають менші значення в порівнянні з техноземами. 

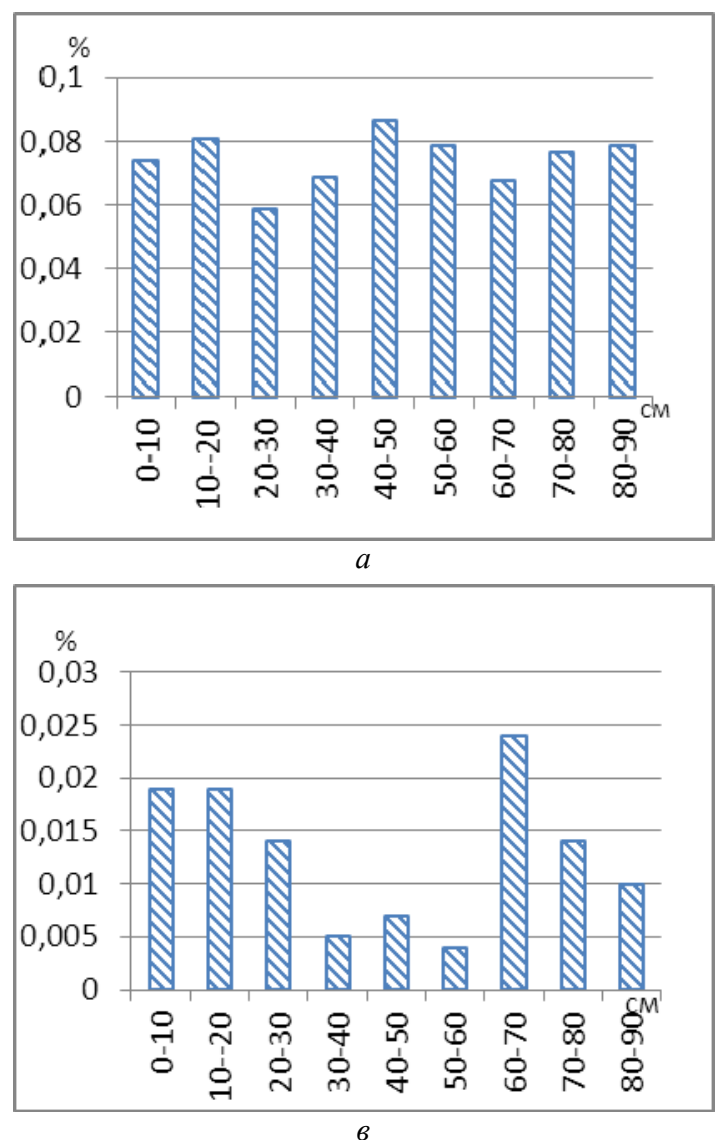
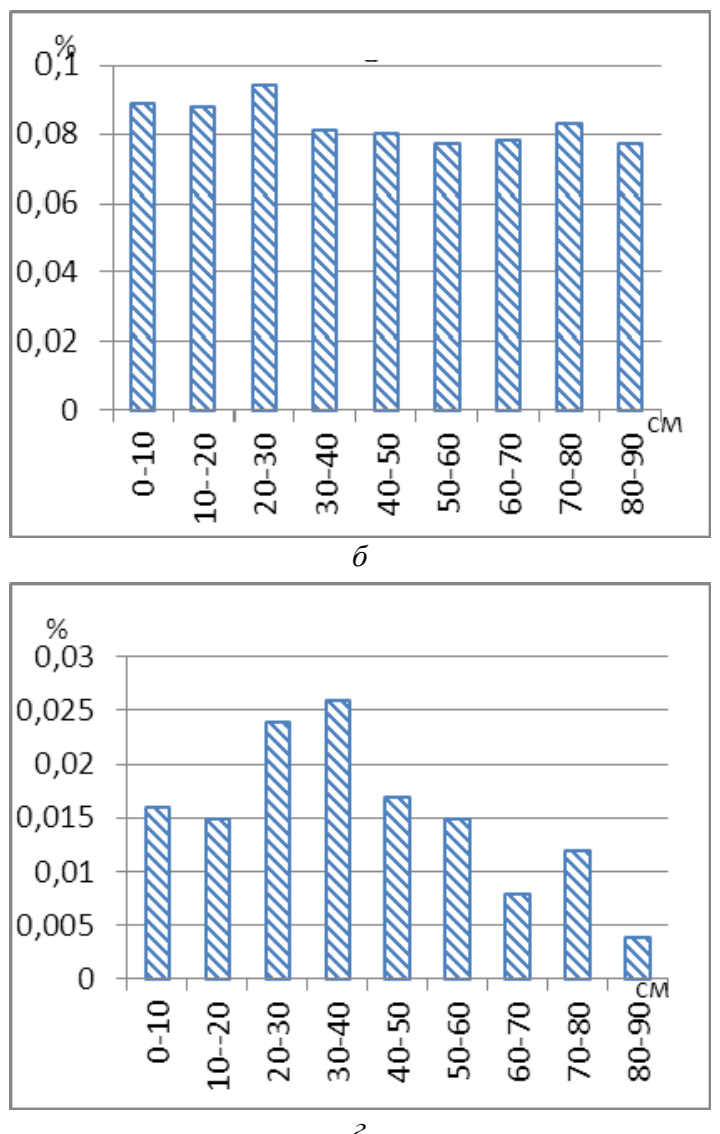

Рис. 1. Вміст загального азоту у профілі педозему $(a)$, технозему на лесоподібному суглинку (б), на червоно-бурій (в) та сіро-зеленій глинах (2)
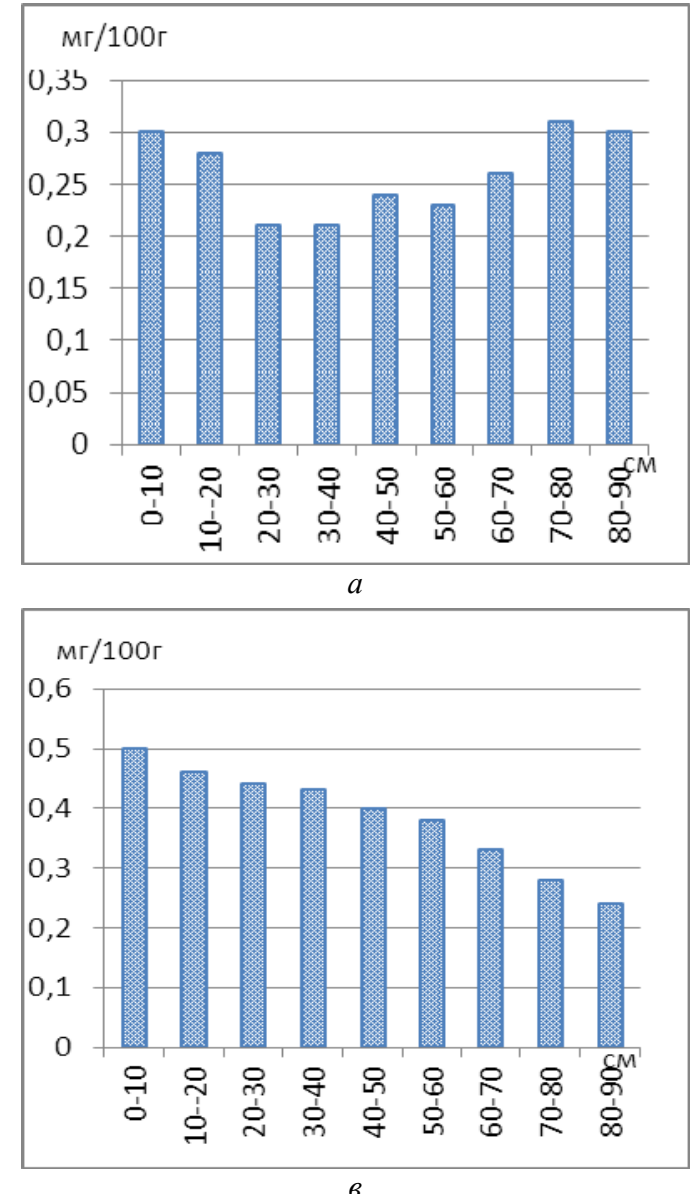
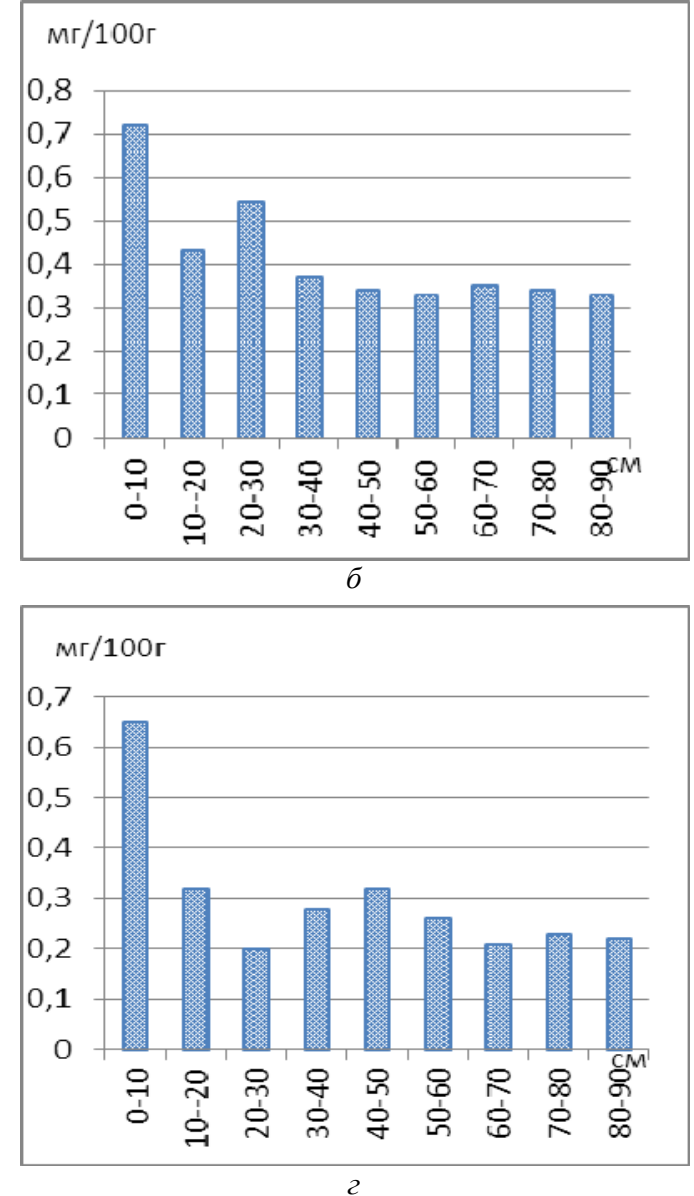

Рис. 2. Вміст розчиненого азоту у профілях педозему (a), технозему (б) на лесоподібному суглинку, червоно-бурій (в) та сіро-зеленій (2) глинах 
Одним із важливих показників, що характеризують продуктивність грунтів, $€$ ферментативна активність. Дослідження в цій галузі проводились багатьма вченими, які визначили високу ефективність даного показника для діагностики динаміки родючості грунтів за різних техногенних і природних впливів на екосистеми. Відомо, що активність окремих ферментів $\epsilon$ надійним тестовим показником процесів,
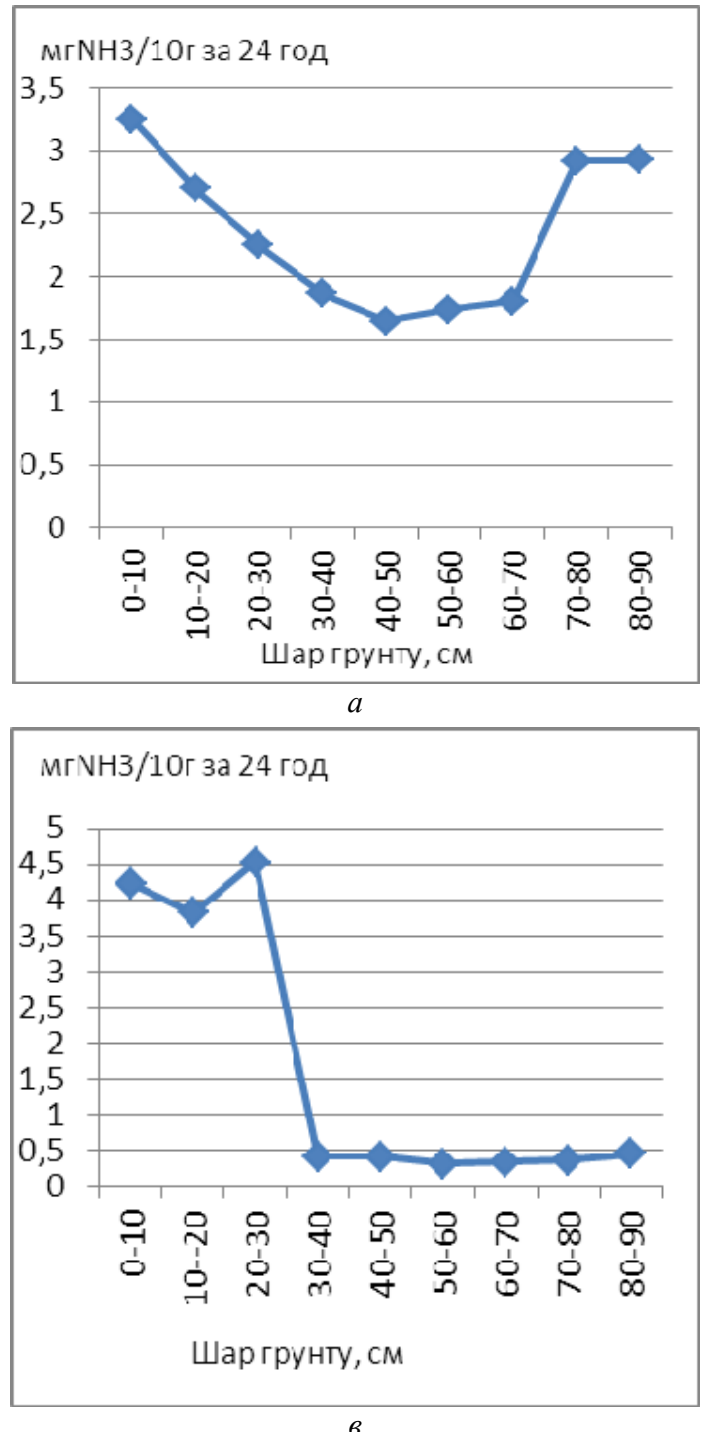

Рис. 3. Активність уреази у профілі педозему (a), технозему на лесоподібному суглинку (б), на червоно-бурій (в) та сіро-зеленій (2) глинах які відбуваються в товщі едафотопів. 3 точки зору агрохімії важливими $\epsilon$ ферменти гідролази. Активність гідролаз характеризує інтенсивність процесів мінералізації органічних речовин, до складу яких входять найважливіші живильні елементи - азот, фосфор тощо (Ahmedova et al., 2014). Експериментальні дані про зміни активності уреази у профілях досліджуваних грунтів представлені на рис. 3.

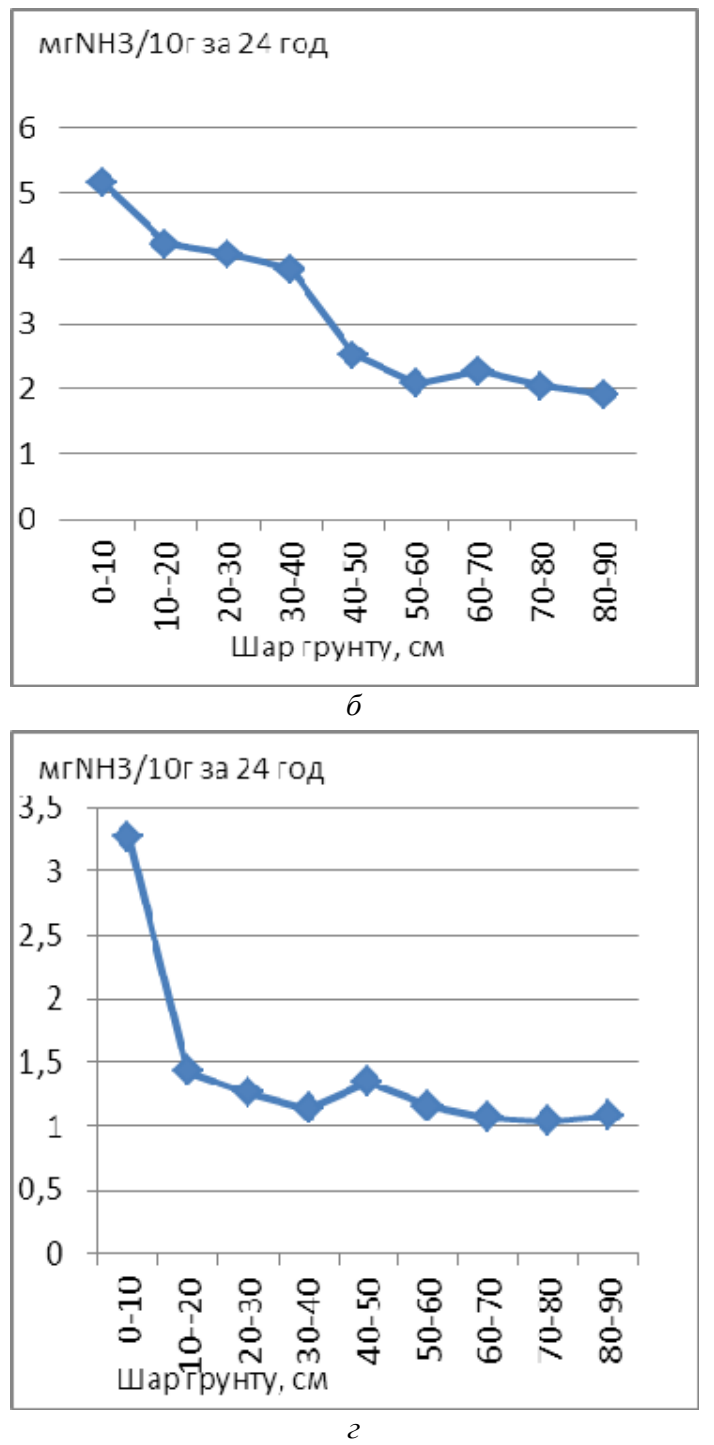




\section{References}

Ahmedova, Z. N., Ramazanova, N. I., Gasanov, G. N. (2014). Fosfataznaya i ureaznaya aktivnost pochv gornyih i ravninnyih landshaftov Dagestana [Phosphate and urease activity of the soils of the mountain and lowland landscapes of Dagestan]. Vestnik Dagestanskogo nauchnogo tsentra, 52, 36-39 (in Russian).

Chorna, V. I., Wagner, I. V., Katsevych, V. V. (2018). Ecologichni osoblyvosti fermentatyvnoi aktyvnosti edafotopiv technogennych landshaftiv [Ecological features of enzyme activity distribution in edaphotops of technogenic landscapes]. Ecology and Noospherology, 29(2), 71-75 (in Ukrainian).

Dadenko, S. V., Kazeev, K. Sh. (2006). Izmenenie fermentativnoy aktivnosti obraztsov pochv pri ikh dlitelnom khranenii [Changes in the enzymatic activity of soil samples during their long-term storage]. Biologiya gruntov, 7(1-2), 80 (in Russian).

Demidov, O. A. (2013). Pertynentsyia na promyslovo porushenykh zemlyakh pivdennogo skhodu Ukrainy
[Pertinence on the industrially disturbed lands of the north east of Ukraine]. Kyiv (in Ukrainian).

Kazeev, K. Sh., Kolesnikov, S. N., Valkov, V. F. (2003). Biologicheskaya diagnostika i indikatsiya pochv: metodologiya i metodyi issledovaniy [Biological diagnostics and indication of soil: methodology and research methods]. Rostov (in Russian).

Khaziev, F. Kh. (2005). Metody pochvennoy enzymologii [Metods of Soil Enymology]. Moscow (in Russian).

Kozlov, K. A. (1964). Fermentativnaya aktivnost pochv kak pokazatel biologicheskoy aktivnosti [Soil enzymatic activity as an indicator of biological activity]. Dokl. sib. pochvovedov VIII Mezhdunar. pochvennomu kongressu. Novosibirsk, 96-106 (in Russian).

Tian, Q. Y., Chen, F. J., Liu, J. X., Zhang, F. S., Mi, G. H. (2008). Inhibition of maize root growth by high nitrate supply is correlated with reduced IAA levels in roots. J. Plant Physiol., 165, 942-951. DOI: 10.1016/j.jplph.2007.02.011.

Tyurin, I. V. (1965). Organicheskoe veschestvo pochvyi i ego rol $\mathrm{v}$ plodorodii [Soil organic matter and its role in fertility]. Moscow (in Russian). 